\title{
FAKTOR YANG MEMENGARUHI PERILAKU PERAWAT DALAM PEMILAHAN LIMBAH INFEKSIUS DAN NON INFEKSIUS DI RUANG RAWAT INAP KELAS 3 RUMAH SAKIT UMUM HAJI MEDAN
}

\author{
M. Solikhul Huda ${ }^{1)}$, Asyiah Simanjorang ${ }^{2)}$, Megawati $^{2)}$ \\ ${ }^{1)}$ Program Studi S2 Ilmu Kesehatan Masyarakat, Institut Kesehatan Helvetia \\ ${ }^{2)}$ Fakultas Kesehatan Masyarakat, Institut Kesehatan Helvetia \\ Email: solikhulhudafkuisu13@gmail.com
}

Diterima: Desember 2020, Diterbitkan: Desember 2020

\begin{abstract}
ABSTRAK
Limbah medis rumah sakit bersifat infeksius dan berbahaya yang harus dikelola sesuai standar operasional prosedur supaya tidak menimbulkan gangguan kesehatan dan pencemaran lingkungan. Rata-rata jumlah limbah medis di RSU Haji Medan per bulan $1.165 \mathrm{~kg}$ dan ruang rawap inap terbanyak penghasilan limbah adalah kelas III. Perawat melakukan pemilahan limbah medis infeksius dan non infeksius belum sesuai ketentuan diduga disebabakan faktor pemahaman, sikap, keterbatasan fasilitas dan informasi serta belum ada penerapan sanksi yang tegas. Tujuan penelitian adalah untuk menganalisis faktor yang memengaruhi perilaku perawat dalam pemilahan limbah infeksius dan non infeksius. Penelitian survei analitik dengan pendekatan cross sectional study. Populasi sebanyak 59 perawat ruang rawap inap kelas III dan seluruhnya dijadikan sampel penelitian. Teknik pengumpulan data menggunakan kuesioner. Data dianalisis dianalisis secara univariat, bivariat dan multivariat menggunakan uji regresi logistik berganda pada taraf kemaknaan $95 \%$. Faktor pengetahuan perawat $(0,019)$, sikap $(0,035)$, ketersediaan fasilitas $(0,038)$, ketersediaan informasi $(0,033)$, dan kebijakan $(0,011)$ berpengaruh terhadap perilaku dalam pemilahan limbah infeksius dan non infeksius karena lebih kecil dari 0,05 , serta faktor pendidikan $(0,943)$ dan lama bekerja $(0,256)$ tidak berpengaruh. Variabel kebijakan sebagai dominan yang memengaruhi dengan nilai $\operatorname{Exp}(\mathrm{B})$ 19,040 .
\end{abstract}

Kata Kunci: Perilaku, Pemilihan Limbah Medis Infeksius, Perawat

\section{ABSTRACT}

Hospital medical waste is infectious and dangerous which must be managed according to standard operating procedures so as not to cause health problems and environmental pollution. The nurses do the sorting of infectious and non-infectious medical waste that are not in accordance with the provisions, allegedly due to factors of understanding, attitude, limited facilities and information and there is no strict sanction application. The aim of the study was to analyze the factors that influence the nurse's behavior in sorting infectious and noninfectious waste.This study was an analytical survey research with a cross sectional study approach. The population was 59 class III inpatient nurses and all of them were used as research samples. The data collection technique used a questionnaire. The data were analyzed using univariate, bivariate and multivariate analysis using multiple logistic regression tests at the 95\% significance level. The nurse's knowledge factor (0.019), attitude (0.035), facility availability (0.038), information availability (0.033), and policy (0.011) influenced the behavior in sorting infectious and non-infectious waste because it was smaller than 0.05, and education factor (0.943) and length of work (0.256) had no effect. The policy variable is dominant which affects the Exp (B) value of 19.040 .

Keywords: Behavior, Infectious Medical Waste Sorting, Nurses 


\section{PENDAHULUAN}

Tenaga kesehatan sebagai provider sebagai pemberi pelayanan kesehatan kepada pasien, di rumah sakit juga sebagai penghasil limbah medis memiliki risiko yang besar terhadap kecelakaan dan penyebaran penyakit sehingga sebagai orang pertama yang berkontak langsung dengan limbah medis dan penghasil limbah medis. Secara global lebih dari 35 juta petugas kesehatan menghadapi risiko luka perkutan akibat terkena benda tajam yang terkontaminasi. Insiden terpapar mikroorganisme yang diobservasi diantara semua tenaga kesehatan yang paling tinggi terpajan adalah perawat disebabkan perawat adalah tenaga kesehatan yang paling sering kontak dengan pasien (Efstathiou, Et. al, 2011)

Penggunaan injeksi sangat tinggi di Pakistan, bahwa 13,6 suntikan per orang diberikan setiap tahun. Lebih dari 50\% dari suntikan tersebut dengan menggunakan jarum suntik bekas pakai. Penggunaan kembali jarum suntik dan recapping jarum mengakibatkan prevalensi Virus Hepatitis B (HBV) dan Virus Hepatitis C (HCV) lebih dari $10 \%$ dan sebagian besar infeksi ini terjadi karena penggunaan jarum suntik (Janjua, et.al, 2007).

Data penelitian pada 114 tenaga kesehatan di 10 puskesmas DKI Jakarta menunjukkan bahwa sekitar $84 \%$ diantaranya pernah tertusuk jarum suntik bekas. Ditemukan prevalensi Hepatitis B surface Antigen (HbsAg) positif sebesar $12,5 \%$ pada kelompok dokter gigi dan $13,3 \%$ pada petugas laboratorium. Padahal pada tenaga kesehatan lainnya dengan insiden sekitar 4\% (Basuki \& Hadi, 2007). Penelitian lain yang dilakukan Hermana (2009) di RSUD Kabupaten Cianjur menyebutkan bahwa jumlah perawat yang mengalami luka jarum suntik dan benda tajam lainnya adalah cukup tinggi yaitu 61,34\%. Data jumlah tenaga kesehatan di faslitas kesehatan lainnya seperti klinik dan puskesmas mengalami infeksi penyakit menular karena jarum suntik dan benda tajamnya lainnya belum diketahui dengan jelas (Hermana, 2008).

Perawat bekerja di rung rawat inap rumah sakit ikut bertanggung jawab atas pemilahan limbah medis karena perawatlah yang bertugas pada ruangan yang menghasilkan limbah medis. Hal ini dikarenakan perawat lebih banyak berperan dalam hal melakukan tindakan pelayanan keperawatan kepada pasien (seperti: menyuntik, memasang selang infus, mengganti cairan infus, memasang selang urine, dan perawatan luka kepada pasien, perawatan dalam pemberian obat, dll) kemungkinan besar perawatlah yang pertama kali berperan apakah limbah medis akan berada pada tempat yang aman atau tidak (tempat pengumpulan sementara alatalat medis yang sudah tidak dipakai lagi), sebelum di kumpulkan dan diangkut ke tempat pembuangan akhir yakni incinerator oleh petugas pengangkut limbah rumah sakit (Pratiwi \& Maharan, 2013).

Pemilahan limbah infeksisus perawat di rumah sakit dapat dikaitkan dengan teori perilaku kesehatan. Menurut Green and Kreuter dalam model Precede menyatakan bahwa perilaku kesehatan dipengaruhi oleh tiga faktor yaitu faktor predisposisi (pengetahuan, sikap, kepercayaan, keyakinan, nilai-nilai, sosio demografi), faktor pendorong (sikap dan tindakan dari petugas kesehatan dan petugas lainnya serta kebijakan) dan faktor pendukung (sarana dan fasilitas kesehatan). Sedangkan cepat atau lambatnya perubahan perilaku dapat berlangsung secara alamiah, terencana dan kesediaan seseorang untuk berubah (Green \& Kreuter,1980)

Rumah sakit dalam memberikan pelayanan keehatan didukung jumlah perawat sebanyak 218 orang dan di ruang rawat inap kelas III 59 orang terdiri dari perawat berstatus Pegawai Negeri Sipil 20 orang dan perawat berstatus honoer 39 orang. Rumah sakit memiliki 250 tempat tidur dan ruang rawat inap terdiri dari VVIP, VIP, Kelas I, Kelas II, Kelas III, ICU, NICU dan PICU yang semuanya 
berlaku bagi pasien BPJS dan KIS (RSU Haji Medan, 2008).

RSU Haji Medan memiliki izin lingkungan berupa Upaya Pengelolaan Lingkungan (UKL) dan Upaya Pemantauan Lingkungan (UPL). Setiap rumah sakit memproduksi limbah medis setiap tahunnya. Rata-rata jumlah limbah medis per bulan tahun 2018 di RSU Haji Medan yaitu $1.165 \mathrm{~kg}$ dan diangkut sekitar 500 $\mathrm{kg} /$ bulan. Proses pengelolaam limbah infeksius padat dimulai dari pengumpulan limbah setiap hari pada waktu pagi, siang dan sore hari. Kemudian dilanjutkan dengan pemilihan jenis limbah padat dan selanjutnya dipilah untuk dimasukkan ke dalam Tempat Penyimpanan Sementara (TPS) (RSU Haji Medan, 2008).

Berdasarkan hasil pengamatan peneliti bahwa limbah infeksius yang paling banyak dihasilkan adalah di ruang rawat inap Kelas III sebagai alasan peneliti menentukan lokasi penelitian .

Rumah sakit melakukan sosialisasi dan pendidikan keselamatan dan kesehatan kerja (K3) tentang pemilahan limbah belum merata dan berkala. Rumah Sakit mempunyai standart operasional prosedur tentang limbah medis cair dan padat yang telah ditetapkan direktur rumah sakit. Rumah sakit belum mengevaluasi kinerja perawat tentang pemilahan limbah dan belum mengidentifikasi aspek-aspek dampak pencemaran limbah medis karena selama ini kasus gangguan kesehatan terhadap pasien tidak pernah ada tetapi ada 4 orang perawat tertutuk jarum saat memilah limbah dan ditemukan jarum suntik oleh petugas Laundy. Perawat juga jarang menggunakan masker dan sarung tangan saat memilah limbah dan tidak mencuci tangan. Ada perawat mencuci tangan tidak menggunakan sabun anti septik. Perawat lain tidak menegur petugas yang tidak lengkap menggunakan alat pelindung diri dan tidak menerapkan sanksi kepada petugas tenaga kesehatan yang tidak membuang limbah medis sesuai warna tempat sampah. Sebagian tenaga kesehatan tidak memiliki buku saku tentang pemilahan limbah medis.

Berdasarkan uraian di atas di atas, maka peneliti tertarik mengkaji judul Faktor yang Memengaruhi Perilaku Perawat dalam Pemilahan Limbah Infeksius dan Non Infeksius di Ruang Rawat Inap Kelas 3 Rumah Sakit Umum Haji Medan Tahun 2018.

\section{METODE PENELITIAN}

Penelitian survei analitik dengan pendekatan cross sectional study. Populasi sebanyak 59 perawat ruang rawap inap kelas III dan seluruhnya dijadikan sampel penelitian. Variabel dependen adalah pendidikan, masa kerja, sikap, pengetahuan, ketersediaan fasilitas, ketersediaan informasi, kebijakan, dan motivasi. Variabel independen adalah perilaku dalam memilih limbah infeksius dan non infeksius. Instrumen penelitian digunakan untuk pengumpulan data penelitian adalah kuesioner. Uji validitas dan reliabilitas dilakukan kepada di RSU Haji Medan sebanyak 30 orang di luar sampel. Uji reliabilitas dilakukan untuk menghitung korelasi corrected item-total correlation dan cronbach alpha. Data dianalisis secara univariat, bivariat uji chi squara dan multivariat uji regresi logistik berganda.

\section{HASIL PENELITIAN}

Perawat yang menjadi sampel penelitian adalah perawat pelaksana di ruang rawat inap kelas III dikelompokkan berdasaran umur produktif. Karakteristik perawat berdasarkan umur lebih banyak tergolong umur produktif diantara 20-40 tahun yaitu 51 orang $(86,4 \%)$, sedangkan umur kurang produktif di atas 40 tahun yaitu 8 orang $(13,6 \%)$. Dilihat dari jenis kelamin lebih banyak perempuan yaitu 53 orang $(89,8 \%)$ dan laki-laki 6orang $(10,2 \%)$. Perawat berdasarkan pernah mengikuti pelatihan yaitu 49 orang $(83,1 \%)$ 
menyatakan tidak pernah dan hanya 10 orang $(16,9 \%)$ pernah mengikuti pelatihan. Latar belakang pendidikan lebih banyak tamatan D III Keperawatan 67,8\%, telah bekerja di atas atau sama dengan 5 tahun $52,5 \%$, berpengetahuan baik 52,5\%, bersikap negatif $54,2 \%$, ketersediaan fasilitas tidak mendukung $67,8 \%$, ketersediaan informasi tidak mendukung $64,4 \%$, dan kebijakan kurang mendukung $66,1 \%$. Perilaku memilah limbah medis infeksius dan non infeksius lebih banyak kurang baik $55,9 \%$.

Terdapat hubungan pengetahuan $(0,002)$, sikap $(0,003)$, ketersediaan fasilitas $(0,004)$, ketersediaan informasi $(0,001)$, dan kebijakan $(0,000)$ dengan perilaku perawat memilah limbah medis infeksius dan non infeksius dengan nilai $\mathrm{p}$ lebih kecil dari 0,05 . Sedangkan variabel pendidikan dan lama bekerja tidak berhubungan dengan nilai p 0,943 dan 0,256 lebih besar dari 0,05.

Berdasarkan tabel 1 diketahui terdapat pengaruh pengetahuan $(0,019)$, sikap $(0,035)$, ketersediaan fasilitas $(0,038)$, ketersediaan informasi $(0,033)$, dan kebijakan $(0,011)$ terhadap perilaku perawat memilah limbah medis infeksius dan non infeksius.

Variabel pengetahuan diperoleh nilai $\operatorname{Exp}(\mathrm{B})$ sebesar 7,077 berarti perawat yang berpengetahuan baik cenderung 7,077 kali berperilaku memilah limbah medis infeksius dan non infeksius daripada berpengetahuan kurang baik. Variabel sikap diperoleh nilai $\operatorname{Exp}(\mathrm{B})$ sebesar 7,932, berarti perawat yang mempunyai sikap positif cenderung 7,932, kali berperilaku memilah limbah medis infeksius dan non infeksius daripada memiliki sikap negatif. Variabel ketersediaan fasilitas diperoleh nilai Exp (B) sebesar 7,184, berarti perawat didukung ketersediaan fasilitas 7,184 kali berperilaku memilah limbah medis infeksius dan non infeksius daripada tidak mendapat dukungan.

Variabel ketersediaan informasi diperoleh nilai $\operatorname{Exp}(\mathrm{B})$ sebesar 7,268, berarti perawat didukung ketersediaan informasi cenderung 7,268 kali berperilaku memilah limbah medis infeksius dan non infeksius daripada tidak mendapat dukungan. Variabel kebijakan diperoleh nilai $\operatorname{Exp}$ (B) sebesar 19,040, berarti perawat didukung penerapan kebijakan yang baik cenderung 19,040 kali berperilaku memilah limbah medis infeksius dan non infeksius daripada tidak mendapat dukungan.

Hasil uji regresi logisitik berganda diperoleh nilai Overall Percentage $=86,4 \%$ yang artinya faktor pengetahuan, sikap, ketersediaan fasilitas, ketersediaan informasi, dan kebijakan memengaruhi perilaku pemilahan limbah medis infeksius dan non infeksius sebesar $86,4 \%$ sisanya $13,6 \%$ dipengaruhi oleh faktor lain yaitu beban kerja, motivasi, budaya.

Tabel 1. Hasil Uji Multivariat

\begin{tabular}{lccc}
\hline $\begin{array}{l}\text { Variabel } \\
\text { Independen }\end{array}$ & Nilai $\beta$ & $\begin{array}{c}\text { Nilai } \\
\boldsymbol{p}\end{array}$ & $\boldsymbol{E x p ( B )}$ \\
\hline Pengetahuan & 1,777 & 0,019 & 7,077 \\
Sikap & 2,348 & 0,035 & 7,932 \\
Ketersediaan & 2,527 & 0,038 & 7,184 \\
fasilitas & & & \\
Ketersediaan & 2,008 & 0,033 & 7,268 \\
informasi & 2,692 & 0,011 & 19,040 \\
Kebijakan & $-6,554$ & 0,001 & 0,002 \\
Constant & O
\end{tabular}

Overall Percentage $=86,4 \%$

\section{PEMBAHASAN}

Penelitian Sari (2018) hasil uji korelasi Spearman menjelaskan tidak ada hubungan yang bermakna antara umur tenaga puskemas dengan praktik pengelolaan limbah medis padat puskesmas Cawas I Kabupaten Klaten dengan nilai $\mathrm{p}>0,05$ yaitu 0,455. Umur tidak berhubungan dengan praktik pengelolaan limbah medis padat Puskesmas Cawas I karena faktor tingkat pengetahuan yang dimiliki tenaga puskesmas (Sari \& Sulistiyani, 2018).

Pada umumnya perawat bekerja di ruang rawat inap kelas III dominan tamatan D III Keperawatan sebesar 67,8\%. Namun pendidikan tidak berpengaruh terhadap perilaku pemilihan limbah medis infeksius 
dan non infeksius. Hal in mungkin disebabkan faktor kesadaran atau tanggung jawab perawat untuk berperilaku memilah limbah medis sesuai peraturan. Jika perawat memiliki kesadaran rendah tetapi berpendidikan tinggi maka perilaku memilah limbah medis tidak sesuai dengan SPO yang telah ditetapkan.

Sejalan dengan penelitian Muthoni (2015) tentang Penilaian Tingkat Pengetahuan Pengelolaan Limbah Medis Rumah Sakit Terpilih di Kenya yang menunjukkan bahwa tidak ada hubungan antara masa kerja tenaga kesehatan dengan praktik pengelolaan limbah medis dengan $p=0,36$. Tingkat pengetahuan dan praktik dalam pengelolaan limbah medis tidak tergantung dari lamanya masa kerja Nurhidayah, 2015).

Pada umumnya perawat telah lama di atas 5 tahun sebesar $52,5 \%$, tentunya memiliki pengalaman bekerja yang cukup dalam memilah limbah medis. Namun masa kerja tidak berpengaruh terhadap perilaku pemilihan limbah medis infeksius dan non infeksius. Hal in mungkin disebabkan faktor pelatihan pemilahan limbah yang masih kurang merata pada perawat di ruang rawat inap kelas III yang memiliki masa kerja di atas 5 tahun maupun di bawah 5 tahun. Pada dasarnya pelatihan merupakan kegiatan yang dapat memengaruhi perubahan pengetahuan, sikap, dan praktik seseorang kearah yang lebih baik.

Penelitian senada dilakukan Nurharyanti (2016) di RSUD Sukoharjo masih ada aktivitas asuhan keperawatan dan pengelolaan sampah medis, jarum, spuit, perban dibuang tanpa dipisahkan, hal ini dibuktikan dengan dilakuan hasil uji Rank Spearman diperoleh nilai $\mathrm{p}=0,001$, artinya terdapat hubungan antara tingkat pengetahuan perawat dengan perilaku perawat dalam pengelolaan sampah medis di ruang rawat inap RSUD Sukoharjo Notoatmodjo, 2014).

Faktor pengetahuan tentang pemilahan limbah medis infeksius dan non infeksius sangat penting untuk ditanamkan pada setiap perawat yang akan melakukan pengelolaan limbah medis rumah sakit. Salah satu upaya untuk meningkatkan pengetahuan dengan memberikan pelatihan atau sosialisasi secara kontinyu melalui breefing dengan menanyakan kepada masing-masing perwat tentang limbah medis sebelum perawat melakukan asuhan keperawatan kepada pasien sehingga perawat berperilaku memilah limbah medis sesuai dengan jenisnya untuk mengurangi dampak terjadinya kecelakaan kerja maupun penyakit infeksi

Penelitian serupa oleh Sudiharti (2012) menyimpulkan hasil penelitiana bahwa terdapat hubungan yang kuat antara tingkat pengetahuan dengan perilaku perawat dalam pembuangan sampah medis $(p=0,002)$ dan terdapat hubungan antara sikap dengan perilaku perawat dalam pembuangan sampah medis di rumah sakit PKU Muhammadiyah Yogyakarta ( $p=$ 0,000 )

Faktor sikap dapat memengaruhi perawat melakukan pemilahan limbah medis infeksius dan non infeksius disebabkan disebabkan tidak ada penerapan sanksi atau teguran dari kepala ruangan sehingga perilaku perawat memilah limbah kurang baik. Kepala ruangan tidak memantau para perawat memilah sampah karena diyakini sudah paham dan mengerti tentang tugas tersebut. Perlunya di masa mendatang manajemen rumat sakit dapat membuat dan menerapkan kebijakan tentang sanksi pemilahan limbah medis infeksius dan non infeksius berupa teguran dan sanksi administrasi dengan menunda gaji berkala bagi perawat yang tidak patuh memilah limbah medis sesuai jenisnya.

Sejalan dengan penelitian Sumiati (2004) di RS Panembahen Senopati Bantul, mengatakan bahwa faktor dominan yang mempengaruhi perilaku karyawan dalam membuang limbah klinis adalah ketersediaan fasilitas pembuangan limbah klinis yang kurang, mempunyai resiko 
mempengaruhi perilaku yang kurang baik Azwar S, 2010).

Ketersediaan fasilitas yang berkaitan langsung dengan pekerjaan pemilahan limbah medis akan diikuti dengan tindakan yang baik oleh petugas. Sesuai dengan nilai $\operatorname{Exp}(B)$ sebesar 7,184, berarti perawat didukung ketersediaan fasilitas 17,184 kali berperilaku memilah limbah medis infeksius dan non infeksius daripada tidak mendapat dukungan. Penyediaan fasilitas tentu menjadi tanggung jawab pihak manajemen rumah sakit sehingga diperlukan perhatian dan pengawasan khususnya dalam pemilahan limbah medis medis. Selain itu, kepada petugas pengumpul sampah limbah medis agar tetap komitmen dalam menjaga dan menggunakan fasilitas penunjang pekerjaan yang telah disediakan oleh pihak rumah sakit.

Menurut Azwar (2009), adanya informasi baru mengenai suatu hal memberikan landasan kognitif baru bagi terbentuknya sikap terhadap hal tersebut. Pesan-pesan sugestif yang dibawa oleh informasi tersebut, apabila cukup kuat akan memberi dasar efektif dalam menilai sesuatu hal sehingga terbentuklah arah sikap dan perilaku tersebut

Faktor ketersediaan informasi memengaruhi perilaku perawat memilah limbah medis infeksius dan non infeksius. Jika ditinjau dari nilai $\operatorname{Exp}(\mathrm{B})$ sebesar 7,184, berarti perawat didukung ketersediaan informasi cenderung 7,184 kali berperilaku memilah limbah medis infeksius dan non infeksius daripada tidak mendapat dukungan.

Untuk itu, pentingnya manajemen rumah sakit melakukan pemeriksaan buku saku sebelum perawat melakukan asuhan keperawatan (breefing) dan bertanya untuk mengingatkan perawat tentang pengelolaan limbah terutama melakukan pemilahan limbah berdasarkan jenisnya. Manajemen rumah sakit juga perlu memberikan reward bagi perawat yang patuh memilah limbah dengan baik seperti pemberian pena/buka, dan handuk sebagai motivasi dalam bekerja.

Sejalan dengan penelitian Tarigan (2009) bahwa adanya peraturan tertulis tentang pengolahan limbah klinis yang diterbitkan rumah sakit dengan mengacu pada peraturan dan didalamnya ada sanksi dan penghargaan pelaksanaan prosedur tetap pembuangan limbah medis padat di unit penghasil limbah medis padat disampaikan kepada perawat akan berpengaruh terhadap tindakan perawat dalam membuang limbah medis padat. Kebijakan rumah sakit berhubungan dengan tindakan responden membuang limbah medis padat (Sudiharti \& Solikhah, 2012).

Pengelolaan limbah medis oleh perawat harus diselenggarakan dengan baik dan tertib untuk mengendalikan risiko yang mungkin ditimbulkan, baik terkait aspek kesehatan maupun pengukuran kinerjanya. Berdasarkan nilai $\operatorname{Exp}$ (B) 19,040, berarti perawat didukung penerapan kebijakan yang baik cenderung 19,040 kali berperilaku memilah limbah medis infeksius dan non infeksius daripada tidak mendapat dukungan dan merupakan faktor dominan dalam meningkatkan perilaku perawat memilah limbah. Pentingya manajemen rumah sakit mengevaluasi kinerja perawat dalam pemilahan limbah medis secara kontrinyu minimal 1 bulan sekali dan

\section{KESIMPULAN DAN SARAN}

Kesimpulan dari penelitian ini adalah aktor pengetahuan perawat, sikap, ketersediaan fasilitas, ketersediaan informasi, dan kebijakan berpengaruh terhadap perilaku dalam pemilahan limbah infeksius dan non infeksius, serta faktor pendidikan dan lama bekerja tidak berpengaruh. Variabel kebijakan sebagai dominan yang memengaruhi. 
DAFTAR PUSTAKA

Efstathiou, Georgios, Papastavio, Raftopoulos, Merkouris. (2011). Factor Influencing Nurses Compliance with Standad Precautions in order to Avoid Occupational Exposure to Microorganisms: A Focus Group Study. BMC Nursing.10(1):1-12.

Janjua, N Z, et.al. (2007). Poor Knowledge-Predictor of Nonadherence to. Universal Precautions for Blood Pathogens at First Level Cara Fasilities Pakistan. BMC Infectius Diseases. 7(81):1-11.

Basuki E, Hadi S, T. (2007). Advokasi sebagai Usaha untuk Membangunan Budaya Kesehatan dan Kesehatan Kerja di Masyarakat. Majalah Kedokteran. 57(3):135-139.

Hermana, AD. (2008) Faktor-Faktor yang Berhubungan dengan Terjadinya Luka Tusuk Jarum atau Benda Tajam Lainnya pada Perawat di Rumah Sakit Umum Daerah Kabupaten Cianjur. Tesis. Universitas Indonesia. Jakarta.

Pratiwi D \& Maharan C. (2013). Analisis Pengelolaan Limbah Medis Padat pada Puskesmas Kabupaten Pati. Jurnal Kesehatan Masyarakat. 9(1):74-84

Green and Kreuter. (1980) Health Education Planning a Diagnostic Approach, USA: The Johns Hopkins University. First Edition.

RSU Haji Medan. (2018) Profil RSU Haji Medan. Medan..

Sari P. F dan Sulistiyani, K A. (2018). Faktor-Faktor yang Berhubungan dengan Praktik Pengelolaan Limbah Medis Padat Puskesmas Cawas I Kabupaten Klaten. Jurnal Kesehatan Masyarakat. 6 (4): 505-515.

Muthoni MS, Nyerere A, Ngugi CW. (2016). Assessment of Level of Knowledge in Medical Waste Management in Selected Hospitals in
Kenya Applied Microbiology: Open Access. Appl Microbiol. ;2(4). doi:10.4172/2471-9315.1000124.

Nurhidayah I. (2015). Hubungan Pengetahuan, Sikap, dan Ketersediaan Fasilitas dengan Perilaku Perawat dalam Membuang Limbah Medis Padat di RS Bhakti Wira Tamtama Semarang. Tesis. Universitas Negeri Semarang.

Notoatmodjo S. (2014). Ilmu Perilaku Kesehatan. Jakarta: Rineka Cipta

Azwar S. (2010). Sikap Manusia-Teori dan Pengukurannya. Yogyakarta: Pustaka Pelajar Offset

Sudiharti, Solikhah. (2012). Hubungan Pengetahuan dan Sikap dengan Perilaku Perawat dalam Pembuangan Sampah Medis di Rumah Sakit PKU Muhammadiyah Yogyakarta.KES MAS;6(1):49-59. 